\title{
PENGARUH ATRIBUT KUALITAS, HARGA, DESAIN DAN PELAYANAN \\ SEPEDA MOTOR HONDA TERHADAP KEPUTUSAN PEMBELIAN \\ KONSUMEN \\ (Studi Kasus Pada PT. ASTRA INTERNASIONAL di MAKASSAR)
}

\author{
Idayanti Nursyamsi \\ Fakultas Ekonomi Universitas Hasanuddin \\ Dani Melmambessy \\ Sekolah Tinggi Ilmu Ekonomi Port Numbay
}

\begin{abstract}
This research aims to find out(1) whether Honda motorbike's attributes involving quality, price, design, and service simultaneously influence consumers' purchasing decision at PT. Astra International in Makassar, (2) whether Honda motorbike's attributes consisting of quality, price, design, and service partially influence consumers' purcahasing decision at PT.Astra Internatonal in Makassar. The sample consisted of 100 respondents as the users of Honda motorbike in Makassar City. The Data were analyzed using multiple linear regression analysis. The result show that (1)simultaneously, motorbike's attributes consisting of quality, price, design, and service have a positive and significant influence on consumers' purchasing decision of Honda motorbike at PT. Astra International in Makassar, (2) partially, quality, price, design, and service attributes have a positive and significant influence on consumers' purchasing decision of Honda motorbike at PT. Astra International in Makassar.

pembelian konsumen pada PT.Astra Internasional di Makassar.
\end{abstract}

Key words : quality, price, design, service, and consumers' purchasing decision.

Kemajuan teknologi dan informasi yang semakin berkembang membuat perusahaan-perusahaan berusaha meningkatkan kualitas produknya menjadi lebih baik. Semua ini dilakukan agar perusahaan lebih kompetitif dari perusahaan lainnya. Pada saat ini perusahaan harus lebih fleksibel terutama dalam era gobalisasi sekarang ini sebagai dorongan bagi setiap perusahaan untuk selalu melalukan inovasi - inovasi yang mampu mengubah selera konsumen dalam mewujudkan kepuasan konsumen.

Peter Drucker seperti dikutip oleh Philip Kotler Mendefinisikan Pemasaran (2007:7) mengatakan bahwa "tujuan pemasaran adalah membuat penjualan tidak terlalu penting lagi". Tujuan pemasaran adalah mengetahui dan 
memahami pelanggan dengan baik sehingga produk atau jasa itu cocok dengan pelanggan dan selanjutnya mampu menjual dirinya sendiri. Idealnya, pemasaran harus menghasilkan pelanggan yang siap membeli. Dalam kata lain, penjualan bukanlah target utama perusahaan. Target utama perusahaan adalah untuk mengetahui produk apa yang diperlukan oleh pasar saat ini, dan menemukan konsumen yang membutuhkannya.

Dalam memilih produk, konsumen tentu saja akan dipengaruhi oleh atribut dari produk tersebut. Atribut produk merupakan segala sesuatu yang melekat dan menyertai produk tersebut: seperti merek, disain, warna, kualitas dan sebagainya. Atribut merupakan salah satu unsur penting yang dapat mendorong konsumen untuk membeli produk, semakin baik atribut produk maka konsumen akan semakin tertarik untuk membeli produk tersebut. Menurut Tjiptono (2007;103) yaitu: "Atribut produk adalah unsur-unsur produk yang dipandang penting oleh konsumen dan dijadikan dasar pengambilan keputusan pembelian.

PT. Astra Honda Motor (AHM) adalah salah satu perusahaan yang bergerak dalam bidang sektor produksi otomotif yang memproduksi sepeda motor Honda dan PT. Astra Internasional selaku perusahaan pemasar sepeda motor Honda juga tidak terlepas akan persaingan yang semakin ketat khususnya dalam industri otomotif karena banyaknya perusahaan-perusahaan yang menghasilkan produk yang sejenis. Oleh karena itu dalam melaksanakan aktivitas penjualannya perusahaan harus dapat merancang strategi pemasaran yang diarahkan untuk menjamin kontinuitas dan tujuan perusahaan dalam jangka panjang, dengan tetap mengacu pada kepuasan konsumen (consumer oriented).

Pangsa pasar sepeda motor Honda pada PT. Astra Internasional Makassar mengalami fluktuasi dari tahun 2005 - 2008 dimana pada tahun 2005 pangsa pasar sepeda motor Honda 43\%, pada tahun 2006 menurun menjadi 42\%, pada tahun 2007 mengalami penurunan menjadi 39\% dan pada tahun 2008 mengalami peningkatan 43\% dengan total penjualan 90.000 unit. Pangsa pasar pesaingnya Honda yaitu sepeda motor Yamaha pada tahun 2005 sebesar 24\%, tahun 2006 naik menjadi30\%, pada tahun 2007 meningkat sebesar 31\% dan pada tahun 2008 
terus meningkat sebesar $32 \%$. Sedangkan pangsa pasar sepeda motor Suzuki pada tahun $200731 \%$.

Keadaan market share sepeda motor Honda di Provinsi Sulawesi Selatan dari berbagai tipe sebagaimana ditunjukkan pada tabel tersebut memberikan gambaran atau fenomena bahwa terjadinya fluktuasi penjualan dan pangsa pasar sepeda motor Honda karena persaingan yang ketat dari merek Yamaha dan Suzuki untuk merebut pangsa pasar. Berbagai faktor terjadi fluktuasi tersebut termasuk atribut sepeda motor terhadap keputusan pembelian para pelanggan atau konsumen seperti desain, harga, kualitas, pelayanan, dan faktor lainnya. Selain itu perubahan selera para pelanggan cenderung berubah dengan cepatnya terhadap atribut sepeda motor dan faktor lainnya.

Dari fenomena tersebut maka PT. Astra Internasional dalam memasarkan sepeda motor Honda dituntut untuk lebih meningkatkan inovasi-inovasi terhadap atribut - atribut produknya sehingga dapat menciptakan inovasi baru yang memilki keunggulan tertentu dalam bersaing, serta mampu mengubah selera para pelanggan dalam melakukan pembelian.

Pengambilan keputusan konsumen untuk melakukan pembelian suatu produk atau jasa di awali oleh adanya kesadaran atas pemenuhan kebutuhan dan keinginan dengan melihat atribut produk. Berbagai macam atribut produk yang ditawarkan oleh perusahaan-perusahaan, terutama Honda, dimana konsumen dihadapkan dengan pilihan-pilihan yang sulit mengenai atribut produk, karena atribut produk yang baik serta dapat memenuhi kebutuhan dan keinginan konsumen sangat relatif bagi setiap konsumen.

Berdasarkan uraian pada latar belakang, maka tujuan dari penulis adalah untuk mengetahui pengaruh atribut kualitas, harga, desain dan pelayanan sepeda motor Honda secara simultan dan partial terhadap keputusan pembelian konsumen pada PT. Astra Internasional di Makassar

\section{METODE}

\section{Populasi dan Sampel}


Dalam penelitian ini yang menjadi populasi adalah konsumen yang melakukan pembelian sepeda motor Honda pada 2008 pada PT Astra Internasional Provinsi Sulawesi Selatan sebanyak 90.000 konsumen. Pemilihan sampel khusus untuk Kota Makassar dilakukan dengan menggunakan metode sampel acak (random sampling) dengan menggunakan rumus Slovin dalam Husain Umar (2001:78) yaitu sebanyak 100 responden.

\section{Teknik Analisa Data}

Sebelum melakukan analisis data maka perlu dilakukan uji validitas, uji reliabilitas, uji heterokedastisitas dan uji mulitikoloneritas. Selanjutnya dilakukan uji hipotesa dengan menggunakan Analisis Regresi Berganda. Formula yang digunakan (Sugiono, 2003 : 234) adalah :

$$
Y=b_{0}+b_{1} X_{1}+b_{2} X_{2}+b_{3} X_{3}+b_{4} X_{4}+e i
$$

Di mana :

$$
\begin{aligned}
\mathrm{Y} & =\text { Keputusan pembelian konsumen } \\
\mathrm{X}_{1} & =\text { Kualitas } \\
\mathrm{X}_{2} & =\text { Harga } \\
\mathrm{X}_{3} & =\text { Desain } \\
\mathrm{X}_{4} & =\text { Pelayanan } \\
\mathrm{b}_{1}-\mathrm{b}_{4} & =\text { koefisien regresi } \\
\mathrm{b}_{0} & =\text { konstanta. }
\end{aligned}
$$

\section{HASIL DAN PEMBAHASAN}

\section{Hasil Pengujian Hipotesis}

Untuk pengujian hipotesis dilakukan sebagaimana uji statistik memberikan jawaban diterima atau tidaknya hipotesis yang di ajukan. Analisis regresi digunakan untuk mengetahui pengaruh atribut kualitas, harga, desain dan pelayanan terhadap keputusan pembelian konsumen sepeda motor Honda pada PT. Astra Internasional di Makassar. Hasil perhitungan merupakan hasil dari pengolahan data statistik dengan menggunakan bantuan program SPSS dapat dilihat pada tabel 1 sebagai berikut : 
Tabel 1

Rangkuman Hasil Uji F dan Uji t Regresi Berganda

\begin{tabular}{|l|c|c|c|c|}
\hline \multicolumn{1}{|c|}{ Variabel } & $\begin{array}{c}\text { Unstan-dardized } \\
(\beta)\end{array}$ & $\begin{array}{c}\text { Unstandar-dized } \\
\text { Standar error }\end{array}$ & $\mathrm{T}$ & Sig \\
\hline Constant & 0,094 & 0,239 & 0,394 & 0,695 \\
Kualitas & 0,297 & 0,061 & 3,648 & 0,000 \\
Harga & 0,231 & 0,107 & 2,155 & 0,034 \\
Desain & 0,250 & 0,086 & 2,902 & 0,005 \\
Pelayanan & 0,183 & 0,081 & 2,257 & 0,026 \\
\hline F-hitung $=73,737$ & \multicolumn{3}{|c|}{ t- tabel $=1,984$} \\
F-tabel Rquared $=0,756$ \\
Sig $=2,48$ & R $=0,870$ \\
\hline
\end{tabular}

Sumber : Data diolah

\section{Pengujian Hipotesis Pertama}

Hasil olahan data dengan SPSS diperoleh F hitung pada tabel Anova sebesar 73,737. Oleh karena F hitung > F tabel berarti secara simultan kualitas $(\mathrm{X} 1)$, harga $(\mathrm{X} 2)$, desain $(\mathrm{X} 3)$ dan pelayanan $(\mathrm{X} 4)$ berpengaruh positip terhadap keputusan pembelian Konsumen (Y) pada PT. Astra Internasional di Makassar.

Secara bersama-sama tingkat signifikansi pada tabel Anova adalah 0,000 $<0,05$ kesalahan pada 95\% kepercayaan atas data. Berarti secara simultan kualitas (X1), harga (X2), desain (X3) dan pelayanan (X4) berpengaruh signifikan terhadap keputusan pembelian konsumen $(Y)$ pada PT. Astra Internasional di Makassar.

Sedangkan koefisien determinasi $\mathrm{R}^{2}$ sebesar 0,756, ini memberikan arti bahwa meningkatnya atau menurunya keputusan pembelian konsumen sepeda motor Honda pada PT. Astra Internasional di Makassar dipengaruhi oleh atribut produk yang terdiri dari kualitas $(X 1)$, harga $(X 2)$, desain $(X 3)$ dan pelayanan (X4) sebesar 0,756 atau (75,6\%) sedangkan sisanya 0,24 atau (24\%) dipengaruhi oleh variabel lain yang tidak di teliti.

Sedangkan koefisien korelasi $(\mathrm{R})$ sebesar 0,875, artinya bahwa variabel atribut yang meliputi kuaitas $(X 1)$, harga $(X 2)$, desain $(X 3)$ dan pelayanan $(X 4)$ terdapat keeratan hubungan yang kuat terhadap keputusan pembelian konsumen (Y) pada PT. Astra Internasional di Makassar.

Dengan demikian hipotesis pertama yang diajukan bahwa terdapat pengaruh signifikan antara variabel-variabel atribut produk yang meliputi kualitas (X1), harga (X2), desain (X3) dan pelayanan (X4) secara bersama-sama 
berpengaruh terhadap variabel keputusan pembelian konsumen sepeda motor Honda (Y) pada PT. Astra Internasional di Makassar.

\section{Pengujian Hipotesis kedua}

Uji-t dilakukan untuk menjawab hipotesis kedua dalam penelitian ini di gunakan untuk membuat kesimpulan mengenai pengaruh dari masing-masing variabel independen $(X)$ secara parsial terhadap variabel dependen $(Y)$ dengan membandingkan nilai thitung dengan nilai $t$ tabel dengan menggunakan derejat bebas $95 \%$ atau $\mathrm{a}=0,05$. Jika nilai $\mathrm{t}$ hitung $>\mathrm{t}$ tabel artinya variabel independen $(\mathrm{X})$ memberi pengaruh terhadap variabel dependen $(\mathrm{Y})$ secara parsial, begitupun sebaliknya.

Untuk melihat perbandingan pengaruh masing-masing variabel atribut produk $(\mathrm{X})$ secara parsial terhadap keputusan pembelian konsumen (Y) pada PT. Astra Internasional di Makassar, maka berdasrkan hasil uji t hitung maka dapat di analisis sebagai berikut :

1. Variabel kualitas (X1) dengan nilai $t$ hitung dan nilai $t$ tabel yaitu 3,684 > 1,984 dengan niali signifikansi 0,000, hal ini dapat diartikan bahwa variabel kualitas mempunyai pengaruh positif dan signifikan terhadap keputusan pembelian konsumen pada PT. Astra Internasional di Makassar.

2. Variabel harga (X2) dengan nilai t hitung dan nilai $t$ tabel yaitu $2,155>1,984$ dengan niali signifikansi $0,034<0,05$, hal ini dapat diartikan bahwa variabel harga mempunyai pengaruh positif dan signifikan terhadap keputusan pembelian konsumen pada PT. Astra Internasional di Makassar.

3. Variabel desain (X3) dengan nilai t hitung dan nilai t tabel yaitu 2,902 >1,984 dengan niali signifikansi $0,005<0,05$, hal ini dapat diartikan bahwa variabel desain mempunyai pengaruh positif dan signifikan terhadap keputusan pembelian konsumen pada PT. Astra Internasional di Makassar.

4. Variabel pelayanan (X4) dengan nilai t hitung dan nilai t tabel yaitu 2,257> 1,984 dengan niali signifikansi 0,026 < 0,05, hal ini dapat diartikan bahwa variabel pelayanan mempunyai pengaruh positif dan signifikan terhadap keputusan pembelian konsumen pada PT. Astra Internasional di Makassar.

Dengan demikian maka dapat disimpulkan bahwa atribut produk yang meliputi kualitas $(X 1)$, harga $(X 2)$, desain $(X 3)$ dan pelayanan $(X 4)$ secara parsial 
berpengaruh positif dan signifikan terhadap variabel keputusan pembelian sepeda motor Honda (Y) pada PT. Astra Internasional di Makassar diterima.

Hasil analisis uji $\mathrm{t}$ terdapat indikasi bahwa variabel kualitas (X1) berpengaruh lebih dominan terhadap keputusan pembelian sepda motor Honda pada PT. Astra Internasional di Makassar.

Berdasarkan hasil olah data computer tersebut pada Tabel 1, maka persamaan regresi linear berganda sebagai berikut :

$$
Y=0,094+0,297 X 1+0,231 X 2+0,250 X 3+0,183 X 4
$$

Persamaan regresi diatas dapat di artikan sebagai berikut :

1. Nilai konstanta 0,094 menunjukkan pengaruh positif terhadap keputusan pemeblian konsumen (Y) pada PT. Astra Internasional jika tidak ada variabel kualitas (X1), harga (X2), desain (X3) dan pelayanan (X4).

2. Koefisien regresi kualitas (X1) sebesar 0,297 diartikan bahwa setiap kali peningkatkan kualitas maka akan berpengaruh positif terhadap keputusan pembelian konsumen (Y) pada PT. Astra Internasional di Makassar sebesar 0,297 dengan asumsi bahwa variabel lain yaitu harga, desain dan pelayanan konstan (cateris paribus).

3. Koefisien regresi harga (X2) sebesar 0,231 diartikan bahwa setiap kali peningkatkan harga maka akan berpengaruh positif terhadap keputusan pembelian konsumen (Y) Pada PT. Astra Internasional di Makassar sebesar 0,231 dengan asumsi bahwa variabel lain yaitu kualitas, desain dan pelayanan konstan (cateris paribus).

4. Koefisien regresi desain (X3) sebesar 0,250 diartikan bahwa setiap kali peningkatkan desain maka akan berpengaruh positif terhadap keputusan pembelian konsumen (Y) pada PT. Astra Internasional di Makassar sebesar 0,250 dengan asumsi bahwa variabel lain yaitu kualitas, harga dan pelayanan konstan (cateris paribus).

5. Koefisien regresi pelayanan (X4) sebesar 0,183 diartikan bahwa setiap kali peningkatkan pelayanan maka akan berpengaruh positif terhadap keputusan pembelian konsumen (Y) pada PT. Astra Internasional di Makassar sebesar 0,183 dengan asumsi bahwa variabel lain yaitu kualitas, harga dan desain konstan (cateris paribus). 
Persamaan tersebut menunjukkan bahwa koefisien berganda $(\beta)$ bertanda positif untuk semua variabel $X$ dan signifikannya $<0,05$. Artinya semua variabel $X$ dalam penelitian ini berpengaruh terhadap keputusan pembelian konsumen (Y) pada PT. Astra Internasional di Makassar.

\section{Pembahasan}

\section{Pengaruh kualitas terhadap Keputusan Pembelian Konsumen}

Hasil analisis tersebut diatas memberikan gambaran bahwa kualitas sebagai atribut yang melekat pada sepeda motor Honda membutuhkan ketahanan/daya tahan fisik dan kapasitas mesin (besar cc) yang perlu mendapatkan perhatian dengan selalu mencari teknik untuk meningkatkan kapasitas dan ketahanan mesin. Kemudahan dalam pemakaian bagi kosumen terkait dengan konstruksi mesin dan teknik pengoperasiannya yang mudah dan tidak merumitkan konsumen. Kemudahan pemeliharaan baik yang berhubungan dengan penggantian spare part atau ketersediaan spare parts di setiap dealer. Disamping itu memungkinkan konsumen membenahi tanpa harus selalu ke bengkel pelayanan perbaikan jika terjadi kerusakan pada bagian tertentu. Pemakaian bahan bakar yang irit adalah merupakan unsur yang terkait langsung dengan konstruksi mesin yang serasi dengan kecepatannya akan menciptakan efisiensi biaya bahan bakar dan pecepatan tempuh yang efektif.

PT. Astra Internasional didalam meningkatkan kualitas motor Honda maka diperlukan pembenahan - pembenahan terhadap kualitas termasuk daya tahan, keandalan, kemudahan pemeliharaan, kemudahan pemakaian dan penggunaan bahan bakar sebagaimana harapan atau persepsi para konsumen terhadap kualitas karena konsumenlah yang merasakan atau menikmati kualitas sepeda motor Honda terebut. Hal ini sesuai dengan yang dikemukakan oleh Sedarmayanti (2005 : 48) kualitas produk atau jasa harus dimulai dari kebutuhan pelanggan dan berakhir pada persepsi konsumen. Hal ini berarti bahwa citra kualitas yang baik bukanlah berdasarkan sudut pandang atau persepsi pihak menyedia produk atau jasa, melainkan berdasarkan sudut pandang atau persepsi konsumen. Konsumenlah yang mengkonsumsi dan menikmati kualitas sehingga merekalah yang seharusnya menentukan kualitas produk atau jasa. Persepsi konsumen terhadap kualitas produk atau jasa merupakan penilaian 
menyeluruh atas keunggulan suatu produk atau jasa dari sudut pandang konsumen.

\section{Pengaruh Harga terhadap Keputusan Pembelian Konsumen}

Hasil analisis deskritif tentang jawaban respoden terhadap harga motor Honda pada PT. Astra Internasional Makassar bahwa para responden menyatakan setuju harga motor Honda dalam hal dengan pembayaran cicilan, kesesuaian dengan manfaat, dan kesesuaan daya beli konsumen

Hasil analisis tersebut diatas memberikan gambaran bahwa harga sebagai atribut yang melekat pada sepeda motor Honda membutuhkan kebijaksanaan dengan pembayaran cicilan, kesesuaian dengan manfaat dan kesesuaan daya beli konsumen. Hasil analisis tersebut sesuai dengan pendapat Tjiptono (2008:151) bahwa dari sudut pandang konsumen harga seringkali digunakan sebagai indikator nilai bilamana dihubungkan dengan manfaat yang dirasakan terhadap suatu barang atau jasa.

\section{Pengaruh Desain terhadap Keputusan Pembelian Konsumen}

Hasil analisis deskriptif tentang jawaban respoden terhadap desain motor Honda pada PT. Astra Internasional Makassar bahwa para responden menyatakan setuju desain motor Honda dalam hal keunikan, keragaman tipe, penamplan dan keragaman warna.

Hasil analisis tersebut diatas memberikan gambaran bahwa disain sebagai atribut yang melekat pada sepeda motor Honda membutuhkan kreativitas para perancang motor Honda baik yang menyangkut keunikan, keragaman tipe, penamplan dan keragaman warna, disamping unsur disaian lainnya yang mampu mengubah atau menggeser selera konsumen untuk melakukan pembelian

Menciptakan keunikan dan keragaraman tipe yang melekat pada motor Honda adalah merupakan hasil dari penelitian atau pengembangan atau dapat juga melalui imitasi atau meniru motor merek lainnya, namun tidak melanggar dari aspek hukum. Penampilan dan keramaman warna yang menarik dapat diciptakan dengan kondisi fisik dan warna yang selalu berubah setiap garis produksi dan memungkinkan tidak mudah ditiru oleh pesaing. 
Didalam proses disain, manajemen selalu berupaya mempelajari dan memahami gaya hidup, faktor sosial dan ekonomi para konsumen agar memudahkan dalam merumuskan proses penciptaan suatu disain atau pengembangan produk, baik dalam hal keunikan, keragaman tipe, penampilan dan keragaman warna yang dapat memenuhi keinginan konsumen sesuai dengan segmennya masing - masing.

\section{Pengaruh Pelayanan terhadap Keputusan Pembelian Konsumen}

Hasil analisis deskritif tentang jawaban respoden terhadap pelayanan yang diberikan pegawai atau salesman PT. Astra Internasional di Makassar menyatakan setuju pelayanan konsultasi, layanan perbaikan, kepedulian dan keramahan yang memuaskan konsumen.

Hasil analisis tersebut diatas memberikan gambaran bahwa pelayanan yang berkualitas oleh para salesman atau karyawan PT. Astra Internasional terhadap kesempatan konsultasi dengan konsumen tentang sesuatu kebutuhan atau kesulitan yang dialami pelanggan baik pada saat membutuhkan informasi misalnya kondisi fisik, maupun pelanggan yang membutuhkan kejelasan penggunaan dan pemeliharaan motor Honda dan layanan perbaikan jika terjadi kerusakan atau pergantian spare part. Kepedulian terhadap kebutuhan atau keluhan konsumen dan keramahan yang memuaskan pelanggan.

Jika konsultasi tidak memuaskan konsumen tentang apa yang dibutuhkan konsumen. Layanan perbaikan atau pemeliharaan sebagai garansi terhadap motor Honda tidak sesuai dengan yang dijanjkan. Kurangnya kepedulian atas keluhan konsumen dan tidak ramahnya pelayanan yang diberikan, maka konsumen akan kecewa karena harapan mereka tidak terwjud. Fenomena ini merupakan pelayanan yang tidak berkualitas dan akan menciptakan image yang buruk terhadap perusahaan

Berdasarkan uraian diatas maka PT. Astra dituntut untuk selalu melakukan evalusi terhadap kinerja pelayanan para sa lesman atau karyawan terhadap kebutuhan, kesulitan atau keluhan-keluhan konsumen agar mendapatkan kepercayaan yang tinggi dari konsumen melebihi para pesaingnya. 
Setelah dilakukan pembahasan terhadap empat atribut sepeda motor Honda (kualitas, harga, desain dan pelayanan), maka PT. Astra Internasional dalam upaya untuk menggiring konsumen mengambil keputusan pembelian motor Honda maka perusahaan harus memiliki kemampuan agar atribut motor Honda tersebut: kualitas ditingkatkan terutama saat produk berada pada titik penurunan pada siklus produk. Kebijaksanaan penetapan harga sesuai dengan manfaat motor yang dihasilkan serta segmen pasar. Disain atau pengembangan produk dengan diversifikasi yang tepat yang mampu membuat konsumen tertarik dan peningkatan kualitas pelayanan kepada konsumen dengan tetap mengacu pada konsep/teori dimensi kualitas pelayanan.

\section{KESIMPULAN DAN SARAN}

\section{Kesimpulan}

Berdasarkan hasil penelitian dan pembahasan, maka dapat ditarik kesimpulan sebagai berikut:

1. Secara simultan atribut kualitas, harga, desain dan pelayanan sepeda motor Honda berpengaruh positif dan signifikan terhadap keputusan pembelian pada PT. Astra Internasional di Makassar.

2. Secara parsial atribut kualitas, harga, desain dan pelayanan sepeda motor Honda berpengaruh positif dan signifikan terhadap keputusan pembelian konsumen sepeda motor Honda pada PT. Astra Internasional Makassar.

\section{Saran}

Dari kesimpulan tersebut maka dalam kaitannya dengan pengaruh atribut sepeda motor Honda terhadap keputusan pembelian konsumen pada PT. Astra Internasional di akassar, maka di sarankan agar unsur - unsur atribut yang meliputi kualitas, harga, desain dan pelayanan agar menjadi dasar pertimbangan bagi PT. Astra Internasional dalam merumuskan kebijakan penjulan dimasa akan datang.

\section{DAFTAR PUSTAKA}

Kotler, P. dan Amstrong, G.. 1997. Prinsip-Prinsip Pemasaran, Jilid 1 Edisi ketujuh. Jakarta: Erlangga 
Kotler. P., and Keller, K.L. 2007. Manajemen Pemasaran, Edisi Keduabelas, Jilid 1, Diterjemahkan oleh Benyamin Molan. Jakarta: Indeks.

Kotrler. P., and Keller, K.L. 2007. Manajemen Pemasaran, Edisi Keduabelas, Diterjemahkan oleh Benyamin Molan, Jilid 2. Jakarta: Indeks.

Lamb. Jr,. Hair Jr,. Mc Daniel. 2001. Pemasaran, Edisi Pertama, Diterjemahkan oleh David Octaveria. Jakarta: Salemba Empat.

Sugiyono. 2008. Metode Penelitian Kuantitatif Kualitatif dan $R \mathcal{E} D$. Bandung: Alfabeta.

Sugiyono. 2002. Statistk untuk Penelitian. Bandung: Penerbit Alfabeta.

Tjiptono. F.. 2007. Strategi Pemasaran, Edisi Kedua. Yogyakarta: Penerbit Andi

Umar. H,. 2001. Studi Kelayakan Bisnis. Jakarta: Gramedia Pustaka Utama.

Kewirausahaan Vol. 10. No. 1. Maret 2008 (30-37) FE- Universitas Kristen Petra Surabaya. ww.Honda.com

...Honda Akui Yamaha dan Suzuki Kuat. Senin 18-02-2008. Tribun Timur.

Penjualan Honda Meningkat. Senin. 15-12-2008. Ekspres Makassar. 